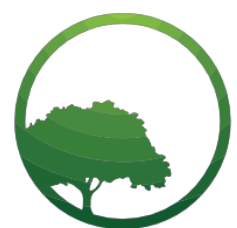

Business \& Social Science IJRBS

\section{Research in Business and Social Science}

IJRBS Vol 8 No 1, ISSN: 2147- 4478

Contents available at www.ssbfnet.com/ojs

\title{
The Contribution of Social Capital and Knowledge Management Towards SMEs Fishery in Ambon City
}

Jolyne Myrell Parera

Corresponding Author: Economics Faculty of Indonesian Christian University, Moluccas, Indonesia ORCID ID: https://orcid.org/0000-0002-6839-9797

\begin{abstract}
Globalization era is marked by the vast development of knowledge, technology and information, which is competitively incline. Considering the fact that the global competitiveness continously grows tighter, the paradigm needs to change from resources-based competitiveness to knowledge-based competitiveness. The study on knowledge management towards fishery SMEs (Small and Medium Entreprises) tends to apply tacit knowledge directly among the persons rather than the explicit knowledge. The knowledge management is believed to be invented due to the role of the social capital in the form of trust, norm, and network that proceeds continuously among both the internal SMEs and external institutions. This research was conducted in Ambon as one of the 'minapolitan area' in Indonesia, and employed descriptive research method and phenomenology approach based on the assumption of reality reconstruction. As the result, this research found that the knowledge management is evidently created as a form of the social capital role both inside and outside the fishery SMEs areas.
\end{abstract}

Key words: Social Capital, Tacit knowledge, Explicit Knowledge, Knowledge Management, Minapolitan Area

JEL classification: $D 83, Q 22, R 11$

Submitted: 06.02.2019 - Accepted: 21.02.2019

\section{Introduction}

The Era of Regional Autonomy implies that the regions plan their own development in their regions with local resource support in order to make the role and position of Small and Medium Enterprises (SMEs) strategically relevant to the successful implementation of decentralization policy. The role of Small and Medium-Scale Enterprise (SMEs) in the national economy cannot be underestimated. These enterprises are being given increasing policy attention in recent years, particularly in third world countries partly because of growing disappointment with results of development strategies focusing on large scale capital intensive and high 


\section{J.M. Parera / International Journal of Research in Business and Social Science,}

Vol 8 No 1, 2019 ISSN: 2147-4486

import dependent industrial plants (Taiwo, Ayodeji, \& Yusuf, 2013). Some argued that SMEs expansion boosts employment more than large firm growth because SMEs are more labour intensive thereby subsidizing SMEs may represent a poverty alleviation tools, by promoting SMEs and individual countries and the international community at large can make progress towards the main goal of halving poverty level by year 2020 i.e to reduce poverty by half and becoming among 20 largest World Economies (Eneh, 2011). One of the preventive measures implemented by the local government is through the Ministry of Marine Affairs and Fisheries of the Republic of Indonesia issued Kepmen.No.32 / MEN / 2010 where the city of Ambon is defined as a minapolitan area. Minapolitan area is a part of the region that has the main function of the economy consisting of core industry, related industries and supporting industries. The aim of minapolitan area is to increase the production, productivity and income of fishermen, as well as to increase the economic growth of the subject area, which in this case is Ambon City.

Fisheries entrepreneurs, in carrying out production, distribution and exchange activities does not only rely on material resources such as capital, technology and human resources alone as determinants of business sustainability, but non-material resources must also be taken into account and consideration. The nonmaterial resource in question is the development of social resources in the form of social capital. In the era of globalization, transformation, technology and information, it shows the weakness of social relationships between entrepreneurs, because most businesses only focus on increasing production, with high profit gain (Shane, 2003). The institutional role that is conceptualized through social capital in building ongoing cooperative relationships will provide an opportunity for the formation of emotional bonds, such as mutual trust based on norms mutually agreed between entrepreneurs (Yustika, 2008; Fukuyama, 1995 \& Braun and Julian, 2006). Thus, forming a network or cooperation, which ultimately can make a mutual exchange between the core industry, related industries and supporting industries (Mudiarta, 2009).

Knowledge has an important role in order to build innovation capability and improve performance quality (Kimura, 2002). Knowledge management in SMEs is created, shared and transferred more using the relationship between tacit knowledge (implicit knowledge) directly between the personal rather than using explicit knowledge, through the media information.

This study aims to give an insight of the process and knowledge management of Fishery SMEs in Ambon City, which is converted from tacit knowledge by portraying social capital as collective strength through cooperation in SME area.

\section{Literature Review}

On the previous research by (Aguilera et al., 2015) stated among fishing communities, fisheries diversification and occupational multiplicity are critical strategies fishermen use to respond to environmental, regulatory, and economic variability and change, and contribute to the viability and welfare of a fishery and associated communities. It is common for fishermen to engage in many different fisheries, using a "portfolio approach," shifting focus among fisheries in response to various social and ecological drivers. Historically, fishermen have shifted effort among fisheries because of (1) management strategies that limit or promote particular gear types, (2) the availability of more valued or abundant species, (3) climate variability, and (4) ease of adapting one's vessel, gear, or location.

The selection of research method of this action research is qualitative research method, based on the assumption that the reconstruction of reality and its meaning is understood as social phenomenon or can be said to interact intensely with the reality which is examined and is natural or what it is (Creswell, 1994; Bungin, 2008 \& Sugiyono, 2005).

Research approach through phenomenology rationality action that researchers try to understand the meaning of events that occur on the investigated based on the reality of the incident occurred, that the phenomenon of fisheries entrepreneur behavior is not a single valid but related to the behavior of other entrepreneurs who mutually support and can be expressed, understood, in depth (Basrowi and Sadukin, 2002 \& Mantra, 2008).

Location of research is Ambon City. It is based on KEPMEN No 32 / MEN / 2010 that Ambon City serve as zone of minapolitan. 
Method of data analysis in research conducted through three stages, namely: 1) Data reduction, where the data reduction will be done simultaneously with the data collection process to complete. 2) Analysis of the domain, the researcher will categorize the various phrases and social-economic realities obtained systematically. 3) Conclusion, verification and reflection. In this process the researcher does an interpretation of the meaning of the empirical data that has been collected and categorized previously systematically. The verification process is repetitive and dynamic in a variety of practical situations and documentation. The process of reflection is done to get a correct and complete understanding of the utterance and meaning behind the utterance becomes a critical point in this study.

\section{A Model Proposal for the Knowledge Management on SME Fisheries}

The rapid development of information technology, hinting that fishery SMEs currently no longer rely on natural resources, but based on knowledge (knowledge-based economy). The observed reality that fishery SMEs in the production and distribution activities rely on tacit knowledge.

Fisheries business is a naturally formed area, because of the potential of natural resources, and adjacent to the fishing ground, so that people or residents who are around the area know how to catch fish (Scott, 2004). Knowledge of how to catch fish is known through tacit knowledge (implicit knowledge). Tacit knowledge is the knowledge stored in the memory of a person obtained from the existence of communication information that occurs continuously, so stored in the memory of intuition, experience and skills that are personal.

Social capital as a product of relations that arise from the interaction between entrepreneurs who are in and around the center of SMEs, interaction and interrelation with related industries and supporting industries. The form of social capital created in fishery SMEs is economically viable, through mutual trust based on mutual agreement, cooperation and mutual good exchange with core industry, supporting industry and related industries. Proactive actions in the context of social capital can help SMEs to access knowledge information (Giorgi, 2003 \& Coleman, 1988).

Knowledge management processes and processes that occur in SMEs, require the dynamics of the transfer of knowledge from the existence of friendship relationships between similar entrepreneurs and entrepreneurs are not similar, the relationship of cooperation with relevant agencies, thus forming a model of knowledge that includes;

(1) management of social capital, in enhancing the ability of personal and group learning;

(2) internal entrepreneurs through internal organizational process development;

(3) ability to manage business network with related industries and supporting industries.

Tacit knowledge is a form of knowledge that is difficult to understand except through participative learning (Arrow, 1962). Explicit knowledge is a form of knowledge that is codified in a language that can be understood and understood by others to encourage behavioral changes in the fishery SMEs.

Observing the occuring phenomena in the city of Ambon fisheries in SMEs, and managing both tacit and explicit knowledge are very important. A scheme of the process would also be required.

(Federico et al., 2017) illustrated the possibilities of explicit knowledge integration and extraction, the integration of automated data analysis methods as well as the combination of both. This supports data exploration, analysis, and gain of tacit knowledge as well as the extraction of knowledge and its sharing with other users.

The model below is a representation of social capital and knowledge management that is collaborated through regular interaction and interaction, thereby creating mutual trust between the core industry, related industries and supporting industries. In the initial stage, the learning process at the level of individuals to rely on tacit knowledge, which is based on experience, observation is intended to earn knowledge collectively on SMEs in need of knowledge improvement. Therefore, the evaluation needs to be done to meet the more creative SME resource. The second stage is doing for knowledge through explicit knowledge that is designed 
to be on a chaotic situation that allows the SME entrepreneurs to have innovative thinking, and less focus on capture fisheries. With innovative thinking, their efforts will increase along with development of creativity. It is hoped that the participants could optimize the relationship of cooperation based on mutual trust and mutual exchange of kindness between entrepreneurs as well as with the relevant agencies, in order to minimize the chaos situation, and to even initiate business opportunities for fish meal.

\section{The Schema Model of Knowledge Management on SME Fisheries}

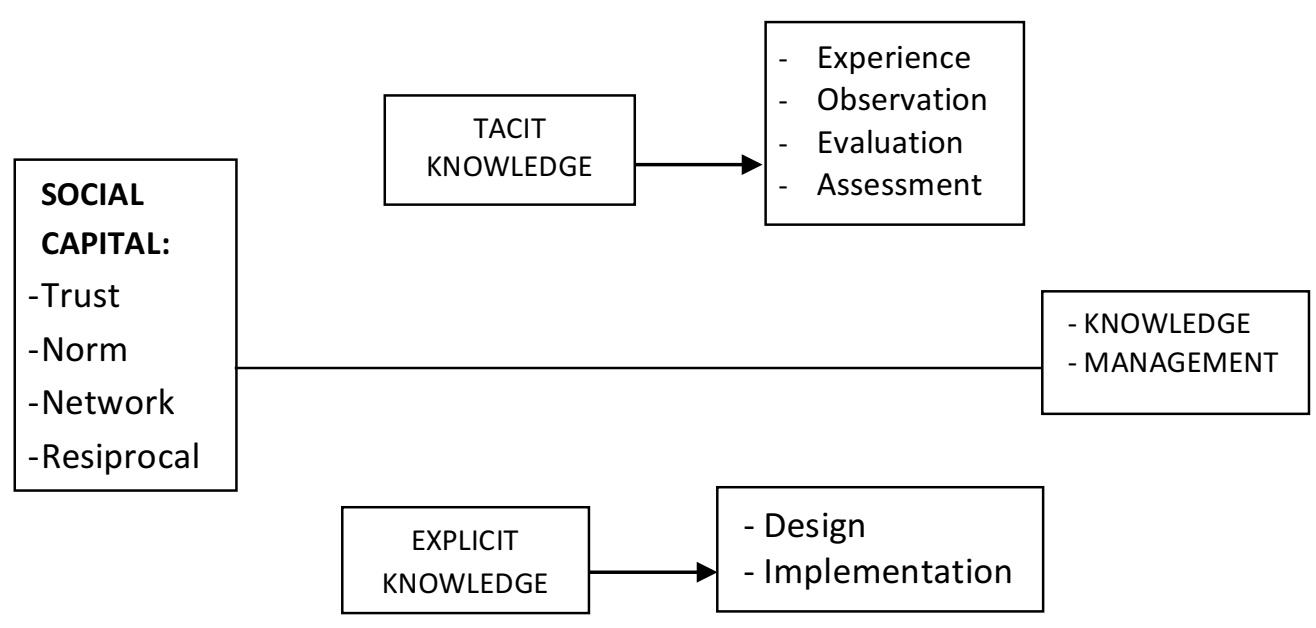

Source: Parera Jolyne in Dissertation, 2012.

\section{Conclusions}

There are three significant points found in this study. Firstly, the individual learning process in the SMEs fishery in Ambon relies on tacit knowledge, which is based on intensive experience and observation. Whereas at the collective level, creative SME resources can develop for expansion of knowledge. Secondly, SMEs fisheries entrepreneurs in Ambon also carry out knowledge through explicit knowledge. This was designed when they overcome such chaotic situation. They optimize cooperative relations based on mutual trust and mutual exchange of good happens between businessmen and related institutions, in order to minimize the chaos occurs, as their initiative to a business opportunity. Lastly, the knowledge management based on the collaboration of social capital is the implementation of innovating ability of SMEs to build the competitiveness as the elemental power of knowledge in SMES fishery area. The implication of this research is that with the existence of social capital and knowledge management, it will help fisheries in Ambon to increase their small and medium enterprises. 


\section{References}

Aguilera, S. E., Cole, J., Finkbeiner, E. M., Le Cornu, E., Ban, N. C., Carr, M. H., ... Broad, K. (2015). Managing small-scale commercial fisheries for adaptive capacity: Insights from dynamic social-ecological drivers of change in monterey bay. PLOS ONE. https://doi.org/10.1371/journal.pone.0118992

Arrow, KJ, 1962. The Economic Implications of Learning by Doing. Review of Economic Studies. 29:155-172.

Basrowi dan Sadukin, 2002. Metode Penelitian Kualitatif Perspektif Mikro. Penerbit Insan Cendikia Surabaya.

Braun Patrice and Julian Lowe, 2006. A Matter of Trust, Networks and Enterpreneurs. Regional Frontiers of Enterpreneurship Research. Paper Present at the Third AGSE International Enterpreneurship Research Exchange, Newzeland, 8-10 Februari, 2006.

Bungin, Burhan, 2008. Penelitian Kualitatif: Komunikasi Ekonomi, Kebijakan Publik dan ilmu Sosial Lainnya. Edisi Pertama, Cetakan kedua. Penerbit. Prenada Media Group. Jakarta.

Coleman, James.S. 1988. Social Capital in The Creation of Human Capital. The American Journal of Sociology. Volume 949S195-S120), Suppl3ement: Organizations and Institutions: Sociological and Economic Approaches to the Analysis of social Structures, JSTOR.

Creswell, John W, 1994. Research Design: Qualitative and Quantitative Approach. California; sge publications, Inc.

Eneh, O. C. (2011). Nigeria's Vision 20:2020-Issues, Challenges and Implications for Development Management. Asian Journal of Rural Development. https://doi.org/10.3923/ajrd.2011.21.40

Federico, P., Wanger, M., Rind, A., Amor-Amorós, A., Miksch, S., \& Aigner, W. (2017). The Role of Explicit Knowledge: A Conceptual Model of Knowledge-Assisted Visual Analytics. In IEEE Conference on Visual Analytics Science and Technology. https://doi.org/10.1109/NAFIPS.2001.944408

Fukuyama Francis, 1995. Trust: The social Virtues and The Creation of Prosperity, New York: the Free Press.

Giorgi, Barbara Piazza. 2003. The Role of Human and Social Capital: Extending our Understanding, Department of Economic, University of the Witwatersrand (unpublished paper).

Kimura, Fukunari 2002. Subcontracting and Performance of Small and Medium Firm in Japan, Small Business Economics 18: 163-175.

Mantra Ida Bagoes, 2008. Filsafat Penelitian dan Metode Penelitian Sosial. Penerbit Pustaka Pelajar.

Mudiarta Ketut Gede, 2009. Jaringan Sosial (Networks) Dalam Pengembangan Sistem dan Usaha Agribisnis : Perspektif Teori dan Dinamika Studi Kapital Sosial.

Parera Jolyne Myrell, 2012. Publikasi Disertasi, Modal sosial Sebagai Input Dalam Proses Aglomerasi dan Implikasinya Terhadap Biaya Transaksi (Studi Pada UKM Perikanan dan Batu Bata) Di Kota Ambon

Scott, A.J, 2004. Entreprenership, Innovation, and Industrial Development: Geography and The Creative I,eld Reviseted. Center for Globalization and Policy Research, UCLA.

Shane, Scott, 2003. A General Theory of Entrepreneurship: The Individual-Opportunity Nexus, Edward Elgar Publishing, Massahusetts, USA.

Sugiyono, 2005. Memahami Penelitian Kualitatif. Penerbit CV. Alfabeta Bandung. 
Taiwo, M. A., Ayodeji, A. M., \& Yusuf, B. A. (2013). Impact of Small and Medium Enterprises on Economic Growth and Development. American Journal of Business and Management. https://doi.org/10.11634/21679606170644

Yustika Ahmad Erani, 2008. Ekonomi Kelembagaan: Definisi, Teori dan Strategi. Penerbit Bayumedia Publishing. 